\title{
Agricultural Expansion and Its Consequences in the Taita Hills, Kenya
}

\section{Pellikka, Petri}

North-Holland Pub. Co

2013

Pellikka , P , Clark , B , Gonsamo Gosa , A , Himberg , N , Hurskainen , P , Maeda , E E , Mwang'ombe , J , Omoro , L \& Siljander , M 2013 , Agricultural Expansion and Its

Consequences in the Taita Hills, Kenya . in P Paron, D Ochieng Olago \& C Thine Omuto (eds), Kenya: a Natural Outlook : Geo-Environmental Resources and Hazards .

Developments in Earth Surface Processes, no. 16 , North-Holland Pub. Co , Amsterdam, the Netherlands , pp. 165-179 . https://doi.org/10.1016/B978-0-444-59559-1.00013-X

http://hdl.handle.net/10138/44808

https://doi.org/10.1016/B978-0-444-59559-1.00013-X

publishedVersion

Downloaded from Helda, University of Helsinki institutional repository.

This is an electronic reprint of the original article.

This reprint may differ from the original in pagination and typographic detail.

Please cite the original version. 


\section{Provided for non-commercial research and educational use only. Not for reproduction, distribution or commercial use.}

This chapter was originally published in the book Developments in Earth Surface Processes, Vol. 16 published by Elsevier, and the attached copy is provided by Elsevier for the author's benefit and for the benefit of the author's institution, for non-commercial research and educational use including without limitation use in instruction at your institution, sending it to specific colleagues who know you, and providing a copy to your institution's administrator.

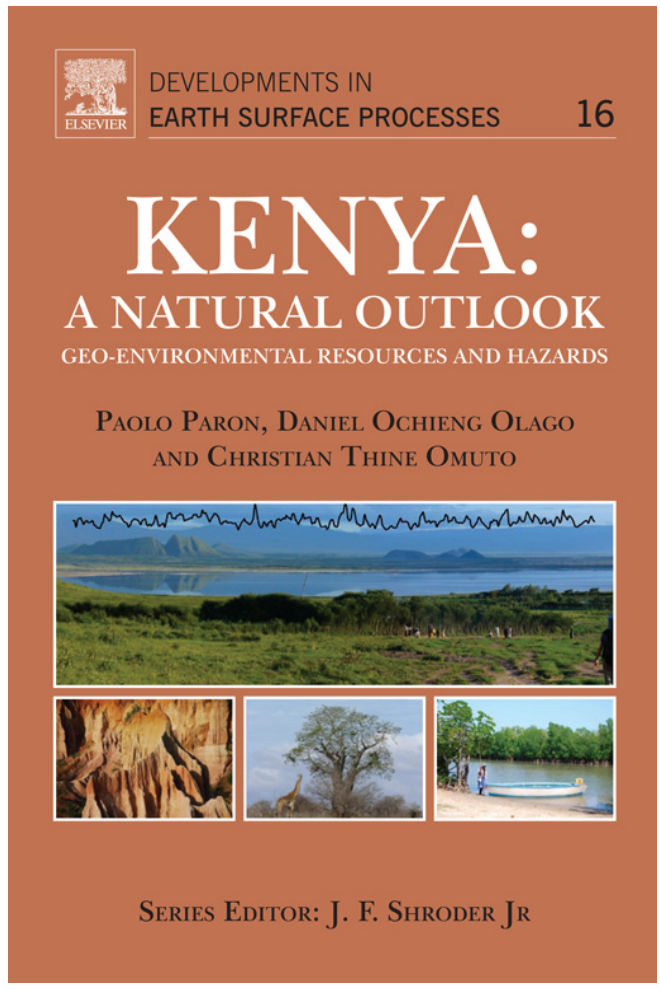

All other uses, reproduction and distribution, including without limitation commercial reprints, selling or licensing copies or access, or posting on open internet sites, your personal or institution's website or repository, are prohibited. For exceptions, permission may be sought for such use through Elsevier's permissions site at:

\section{http://www.elsevier.com/locate/permissionusematerial}

From: Petri K.E. Pellikka, Barnaby J.F. Clark, Alemu Gonsamo Gosa, Nina Himberg Pekka Hurskainen, Eduardo Maeda, James Mwang'ombe, Loice M.A. Omoro and Mika Siljander, Agricultural Expansion and Its Consequences in the Taita Hills, Kenya. In Paolo Paron, Daniel Olago and Christian Thine Omuto, editors:

Developments in Earth Surface Processes, Vol. 16, Amsterdam: The Netherlands, 2013, pp. 165-179.

ISBN: 978-0-444-59559-1

(C) Copyright 2013 Elsevier B.V. 


\title{
Agricultural Expansion and Its Consequences in the Taita Hills, Kenya
}

\author{
Petri K.E. Pellikka*, Barnaby J.F. Clark*, Alemu Gonsamo Gosa ${ }^{\dagger}$, \\ Nina Himberg , Pekka Hurskainen*, Eduardo Maeda*, \\ James Mwang'ombe ${ }^{\S}$, Loice M.A. Omoro and Mika Siljander* \\ *Department of Geosciences and Geography, University of Helsinki, Helsinki, Finland \\ ${ }^{\dagger}$ Department of Geography and Planning, University of Toronto, Toronto, Canada \\ ${ }^{\ddagger}$ Faculty of Agriculture and Forestry, University of Helsinki, Helsinki, Finland \\ ${ }^{\S}$ Kenya Forest Service, Kenya
}

\section{INTRODUCTION: LAND-COVER CHANGE IN SUB-SAHARAN AFRICA}

Africa had lost $16 \%$ of its forests and $5 \%$ of its woodlands and grasslands over the period of $1975-2000$, equating to over $50,000 \mathrm{~km}^{2}$ per year of natural vegetation. Most of the land change is associated with agriculture: between the years 1975 and 2000, the agricultural areas increased by $57 \%$ in sub-Saharan Africa (Brink and Eva, 2009). While the increase of agricultural production on the other continents in the world is based on improving technology as intensified use fertilizers and machinery, in sub-Saharan Africa, the increase of food production is still highly dependent on clearing more land for agriculture. In the future, land grabbing is expected to cause even more intensified increase of croplands as African land is also demanded by non-African nations in order to secure their food security. Also, natural land-cover change may exist due to changes in precipitation pattern or fires (McMichael and Hope, 2007), which may foster human populations to seek arable land elsewhere or to change their farming practices or crops (Maro, 1988; Sunderlin et al., 2000).

The forest loss is especially hard on areas with high biodiversity and in the Afromontane areas, where the decrease is estimated to be $3.8 \%$ annually according to Eva et al. (2006). A significant part of Afromontane Africa is in Kenya. Besides the continental scale studies of land changes (Brink and Eva, 2009), many forest or land-cover-change studies in East Africa indicate 
intensified land use pressure, evidenced by the loss of forests or bushlands after the 1950s (Imbernon, 1999; Lung and Schaab, 2006; Baldyga et al., 2007; Clark and Pellikka, 2009; Pellikka et al., 2009). This study highlights the results of 10-year-long study of land-cover changes in the Taita Hills in southeastern Kenya.

\section{STUDY AREA: THE TAITA HILLS ARE ISLANDS IN THE SEA OF SAVANNA}

The verdant and humid Taita Hills offer a unique venue for land change studies as it is located on the dry Tsavo plains between the Tsavo East and West National Parks, constraining the human population and agricultural lands to expand naturally to the plains. The hills cover an area of $1000 \mathrm{~km}^{2}$ and are surrounded by semiarid Acacia/Commiphora shrubland and dry savanna. While the surrounding plains are at an elevation of 600-900 masl, the Taita Hills rise abruptly in a series of ridges with the highest peak of Vuria at $2208 \mathrm{~m}$, although the average elevation of the hills is $1500 \mathrm{~m}$ (Figure 1). The climate is influenced by the Intertropical Convergence Zone, which leads to a bimodal rainfall pattern, with long rains during March-June and short rains in October-December, although the annual variability of precipitation is high. Located $150 \mathrm{~km}$ from the Indian Ocean, orographic rainfall plays an important part in the local climate as the hills form the first significant barrier, which moisture-laden air encounters. Mist and cloud precipitation occurs throughout the year; consequently, while the annual rainfall is circa $600 \mathrm{~mm}$ on the plains, it is over $1200 \mathrm{~mm}$ in the hills (Beentje and Ndiang'ui, 1988). A rain shadow effect is discernable on the northwestern side of the hills, with the distinctive Euphorbia candelabrum and more commonly Euphorbia bussei var. kibwezensis growing in the drier conditions.



FIGURE 1 The plains in the front of the Taita Hills are at 950 masl in the southwest, while the highest peak Vuria in the middle reaches 2208 masl (Photograph: Petri Pellikka, 2012). 
In prehistorical times, the Taita Hills may have been covered by hundreds of square kilometres of indigenous rain forests, but due to its favourable climatic and edaphic conditions, the forests have been cleared for agriculture from long ago. Many authors take it for granted that $1 \%$ of the forests remain, but none seem to know how this $1 \%$ is derived or by who. The degradation and fragmentation of the forests was noted early (Hildebrandt, 1877), with observations that the slopes were cleared for agriculture up to the head of all streams. Large-scale decreases in forest cover were caused by railway construction and traffic in the early 20th century, and before the introduction of the black wattle (Acacia mearnsii) for the tannin industry, the overall tree cover may have been at its lowest. Exotic trees such as cypress (Cupressus lusitanica), blue gum (Eucalyptus spp.) and pines (Pinus ssp.) were introduced between the 1960s and 1980s and Maesopsis eminii and silver oak (Grevillea robusta) during the late 1970s and 1980s. While eucalyptus, pine and cypress were planted for wood production, silver oak was planted within the fields to support farmers with building material and to decrease the pressure on the indigenous forests. The conservation of indigenous forests began in 1977 by the presidential decree banning the cutting of indigenous forests without a licence (Himberg et al., 2009). Based on the visual analysis of the airborne remote sensing data of the 1950s and presently, as well as landscape photographs taken in 1924, 1957 and 1992 (Turner et al., 1998), the Taita Hills are characterized by small exotic plantations among intensive agriculture with terraced fields in the 1990s and 2000s, while during the 1950s, terracing was almost absent and a significant part of the land in the hills was used as pastures. Even though there were more indigenous bushland and small forest patches during the 1950s, there were practically no trees on farms.

The Taita Hills are also part of a very important biodiversity hotspot. It is the northernmost part of Africa's Eastern Arc Mountains, which have been identified as one of the top 10 biodiversity hotspots in the world, and with over $90 \%$ forest loss during the last 200 years, the hills rank among the most threatened sites of it (Lovett and Wasser, 1993). The Taita Hills continue to boast an outstanding diversity and endemism of flora and fauna (Beentje and Ndiang'ui, 1988). Of particular scientific and conservation interest are the indigenous forest patches. Today, only a small amount of native forest remains, occurring in a scatter of four larger hilltop remnants and further much smaller fragments embedded in a mosaic of human settlements, smallholder cultivation plots and plantations of exotic tree species. The indigenous forest cover not only has been termed upland moist or mist forest by Beentje and Ndiang'ui (1988) but also is referred to as montane forest or cloud forest by other workers. The characteristic tree species include Newtonia buchananii, Tabernaemontana stapfiana, Macaranga conglomerata, Albizia gummifera, Phoenix reclinata, Strombosia scheffleri, Cola greenwayi, Podocarpus spp., Ochna holstii and Millettia oblate (Rogers et al., 2008; Omoro et al., 2010). These indigenous forest patches also play an important role in both capturing additional moisture and storing the precipitation on the hilltops. 
The population of the whole Taita Taveta District has grown from 90,000 persons in 1962 to over 300,000; consequently, this has been a driving factor behind the land use change in the Taita Hills. There has been an increase in the area under cultivation, and due to poor agricultural management, erodible soils and rough topography in the hills, the foothills are subject to land degradation and soil erosion (Muya \& Gicheru, 2005). The remnant forests are threatened by encroachment (for settlement, agriculture and livestock grazing), extraction of firewood and building materials, poor enforcement of government policies and regulations and lack of awareness among the communities living adjacent to forests, fires and colonization by suppressive and fast-growing exotic tree species (EAWLS, 2005). The situation in the Taita Hills, however, is not hopeless compared to the neighbouring Sagala Hills some $20 \mathrm{~km}$ apart.

Because of its unique biogeographic history, the Taita Hills have been under research during the last decade concentrating on the impact of forest fragmentation and degradation on different components of biodiversity (Bytebier, 2001), forest health monitoring (Rogers et al., 2008) and population ecological and genetic studies on bird, mammal, amphibian and insect species (Lens et al., 2002).

The University of Helsinki has been studying the land-cover changes of the Taita Hills since the late 1980s (Pellikka, 1990) but more intensively since 2003. The main objectives have been to develop methodologies for landcover-change studies applying remote sensing and geographic information systems; to assess the land-cover changes in the Taita Hills and its surrounding lowlands; and, finally, to research the consequences of land-cover changes to climate, water resources, biodiversity and livelihoods. The research has resulted in more than 23 M.Sc. theses and seven Ph.D. theses (Soini, 2006; Gonsamo Gosa, 2009; Clark, 2010; Himberg, 2011; Maeda, 2011; Siljander, 2010; Omoro, 2012). Located in the middle of the Tsavo plains and having its small water towers (Ngangao, Vuria, Chawia, Mbololo and Yale), the Taita Hills are like a miniature of Kenya and serve as a model for land-cover change in Kenya.

\section{MATERIAL AND METHODS: LAND-COVER-CHANGE STUDIES USING TWO SCALES}

Land-cover-change studies have been carried out in two scales. In the finescale study, airborne remote sensing data were applied to study the forest cover changes between 1955 and today in the Taita Hills, while in the coarse-scale study, multispectral SPOT XS satellite imagery has been applied to study land changes between 1989 and today in the surroundings of the Taita Hills.

Black and white aerial photography used in the fine-scale study was acquired during January-February 1955 by the Survey of Kenya at a scale of 1:30,000. The prints were scanned using a resolution of $14 \mathrm{~mm}$ resulting 
to ground resolution of $46 \mathrm{~cm}$. The colour airborne digital camera data were acquired during January 2004 using NIKON D1X colour digital camera equipped with a $14 \mathrm{~mm}$ lens producing approximately $40 \mathrm{~cm}$ ground resolution. The individual frames were mosaicked to a seamless orthorectified image mosaic using EnsoMOSAIC software in which the aerial photographs of 1955 were co-registered (Pellikka et al., 2009). The land cover of Ngangao, Chawia, Fururu, Macha, Mwachora and Yale forest fragments of the Taita Hills was classified visually on a computer screen using 2004 data producing eight forest classes (indigenous, eucalyptus, pine, cypress, silver oak, black wattle, mixed exotic and bushland) and eight other classes (rock, built-up, water, agriculture, wetland, barren land, agroforestry and heathland dominated by giant heather (Erica mannii)). The class structure was recorded using the Land Cover Classification System (LCCS), which is a standardized classification system developed by the Food and Agriculture Organization (FAO) of the United Nations and the United Nations Environment Programme (Di Gregorio, 2005). In 1955, no exotic plantations except black wattle existed in the area, and therefore, the 1955 data were classified into indigenous forest, rock, bushland, heathland and barren land classes only. The land-cover model was created in ArcGIS from which the area for each land-cover class was summed. The area of the indigenous forest of each fragment and total forest area including indigenous forest, exotic forests and bushlands were recorded. The change detection was analysed by the areal change, by percentage change and also by change trajectory analysis (Pellikka et al., 2009).

The SPOT XS satellite data used were from 1 July 1987, 25 March 1992 and 15 October 2003, with a $20 \mathrm{~m}$ pixel resolution and green, red and nearinfrared (NIR) spectral bands. All images represent dry conditions, despite the non-anniversary dates, and share very similar off-nadir sensor view angles. Besides orthorectification and coregistration, atmospheric and topographic effects affecting reflectance characteristics were removed (Clark and Pellikka, 2009). LCCS was applied to record the following classes: cropland, shrubland, thicket, woodland, exotic forest, broad-leaved closed-canopy forest (indigenous rain forest), grassland with scattered shrubs and trees, bare soil and other unconsolidated material, built-up area, bare rock and water. For the initial classification, object-based segmentation algorithms of Definiens were applied. The accuracy for the 2003 data was assessed in the field work and with the airborne remote sensing data of 2004. An overall accuracy of 89\% was reached after manual editing (Clark and Pellikka, 2009).

A geospatial database containing layers such as road network, hydrography, administrative borders and digital elevation model (DEM) was generated from a scanned topographic map of a 1:50,000 scale of the Survey of Kenya. The resulting DEM had a $20 \mathrm{~m}$ raster in a transverse Mercator projection with a Clarke 1880 spheroid and Arc 1960 datum and a planimetric accuracy of $50 \mathrm{~m}$ with an altimetric accuracy of $8 \mathrm{~m}$ (Clark and Pellikka, 2009). Mean monthly precipitation surfaces were produced from monthly rainfall records 
of 11 stations within the Taita Hills from 1987 to 2005 obtained from the Kenya Meteorological Department (Erdogan et al., 2011), and soil information was derived from the Exploratory Soil Map of Kenya of scale a 1:1,000,000 (Sombroek et al., 1980).

Using the results from the land-cover classification of satellite imagery and additional datasets, the soil erosion potential of the Taita Hills was assessed using the Universal Soil Loss Equation (USLE) (Wischmeier et al., 1958). The parameters required by the USLE are rainfall erosivity factor $(R)$, slope-length and slope-steepness factor (LS), soil-erodibility factor $(K)$, cover-management factor $(C)$ and support-practice factor $(P)$ for its application. Rainfall erosivity factor, slope factor and soil-erodibility factor are estimated using rainfall data, DEMs and soil maps, respectively. A supportpractice factor is applied if man-made soil-control infrastructure is used in the study area. In this study, support-practice factor was used as a constant value and cover-management factor was derived from land-cover classification using the SPOT XS imagery (Erdogan et al., 2011).

Using the remote sensing data, the forest cover changes of the indigenous forest fragments between 1955 and 2004 were studied, the land-cover changes in the Taita Hills and its surroundings were studied between 1989 and 2003. The results were used also for simulating agricultural expansion scenarios up to 2030 in the study area using a spatially explicit model of landscape dynamics (Maeda et al., 2010a) and also to model soil erosion potential changes from 1989 until 2030 (Maeda et al., 2010b).

\section{RESULTS: LOSS OF INDIGENOUS FORESTS IN THE HILLS AND AGRICULTURAL EXPANSION IN THE LOWLANDS}

The results of the fine-scale assessment indicate that the indigenous forest in the Taita Hills decreased by 50\% (260 ha) between 1955 and 2004, but the total forest cover area decreased only by $2 \%$ due to the establishment of exotic plantations (Pellikka et al., 2009). Each individual forest fragment, however, was managed differently during this time period. The indigenous forest decreased in Chawia, Fururu, Macha, Mwachora, Ngangao and Yale by $28 \%, 76 \%, 78 \%, 68 \%, 20 \%$ and $70 \%$, respectively (Table 1). Based on the change detection results, the indigenous forest was changed not only to agricultural areas but also to some extent to exotic plantations. The exotic plantations were typically established not only in barren and dry areas but also in forests and on agricultural areas. In total, 264 ha of non-forested areas was changed to exotic plantations, while 33 ha was converted to indigenous forest. The conversion to indigenous forest is mostly caused by fast growth of succession species such as $P$. reclinata on abandoned open areas, but in places, such as at the top of Ngangao, primary indigenous forests have developed in areas that were non-forested in 1955. The change of the Ngangao Forest is presented in Figure 2. 
TABLE 1 The Change of Non-Forested Area to Forests in Hectares Between 1955 and 2004 in Selected Study Areas in the Taita Hills

\begin{tabular}{lcc}
\hline Change from $\mathbf{1 9 5 5}$ to $\mathbf{2 0 0 4}$ & To Indigenous Forest & To Exotic Forest \\
\hline Chawia & 3.2 & 9.2 \\
\hline Fururu & 4.1 & 45.1 \\
\hline Macha & 1.7 & 23.8 \\
\hline Mwachora & 1.0 & 10.1 \\
\hline Ngangao & 12.0 & 81.5 \\
\hline Yale & 11.1 & 94.2 \\
\hline Total & 33.1 & 263.9 \\
\hline
\end{tabular}

Adapted from Pellikka et al. (2009).



FIGURE 2 Airborne digital camera image mosaic of 2004 on the left and aerial photograph of 1955 on the right. In the middle is analysed change in which the black colour indicates constant indigenous forest from 1955 to 2004. 
As a result of a coarse-scale study, the croplands covered $239 \mathrm{~km}^{2}$ in 1987 in the Taita Hills and its surroundings, but the area had increased to $244 \mathrm{~km}^{2}$ by 1992 and to $331 \mathrm{~km}^{2}$ by 2003 (Clark and Pellikka, 2009). This increase was caused mainly by conversion of thicket and shrublands to croplands in the lowlands and foothills. Grasslands increased by $4 \mathrm{~km}^{2}$ by conversion from shrublands, especially between the years 1992 and 2003. Plantation forests increased in area, which may be caused by a maturing of the stands, increased biomass and consequent improved identification in the classification process. There was no important change in the area of broad-leaved closed-canopy forests (indigenous forests) between 1987 and 2003 in the main three fragments of Chawia, Ngangao and Mbololo. The large increase in bare soil may be partially caused by phenological effects, since the 1987 image was taken in July after the rainy season, while the 2003 image was taken at the end of the dry season (Figure 3). However, by applying an object-oriented classification method, misclassifications were reduced to as low a level as possible. The decrease in water is mainly caused by the decrease of the water surface in the Mwatate reservoir due to silting of the reservoir.

The land-cover-change scenario is presented with the historical land use maps for 1987 and 2003 in Figure 4 (Maeda et al., 2010a). The land use for 2030 resulted from two land-cover-change scenarios: unrestricted businessas-usual (BAU) scenario and restricted governance (GOV) scenario. It is observed that, in 1987, croplands were already clearly established in the highlands. The protected areas, situated in the northeast (grassland area) and southwest parts of the study area, were effective in containing the agricultural expansion between 1987 and 2003. The influence of this variable was reflected in both simulated scenarios, where a clear boundary constraining
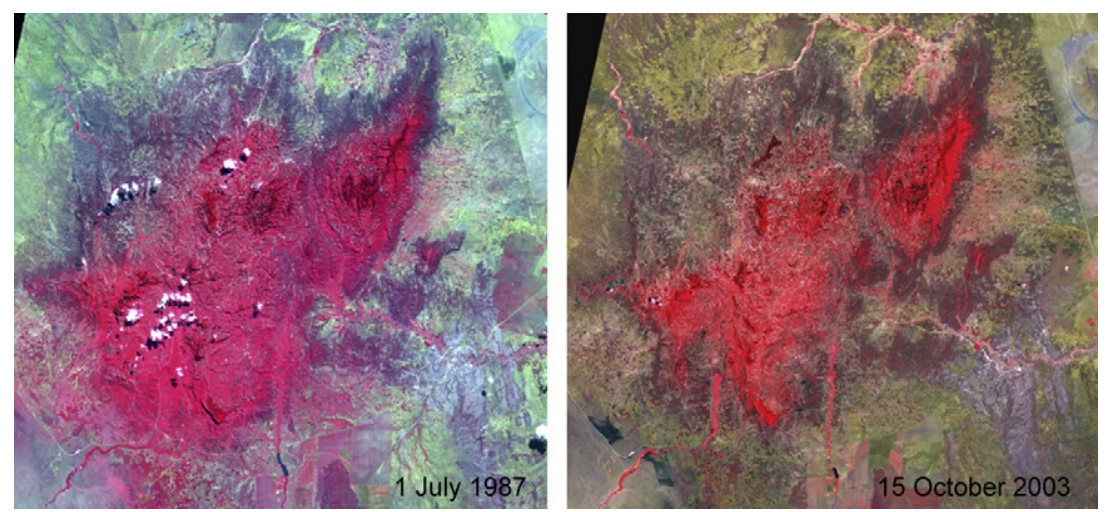

FIGURE 3 The SPOT XS image of 1 July 1987 taken at the end of the long rains represents completely different greenness compared to the image taken on 15 October 2003 after the dry season. The evergreen indigenous forest patches are much more visible from the landscape during the dry season when the fields are bare. 

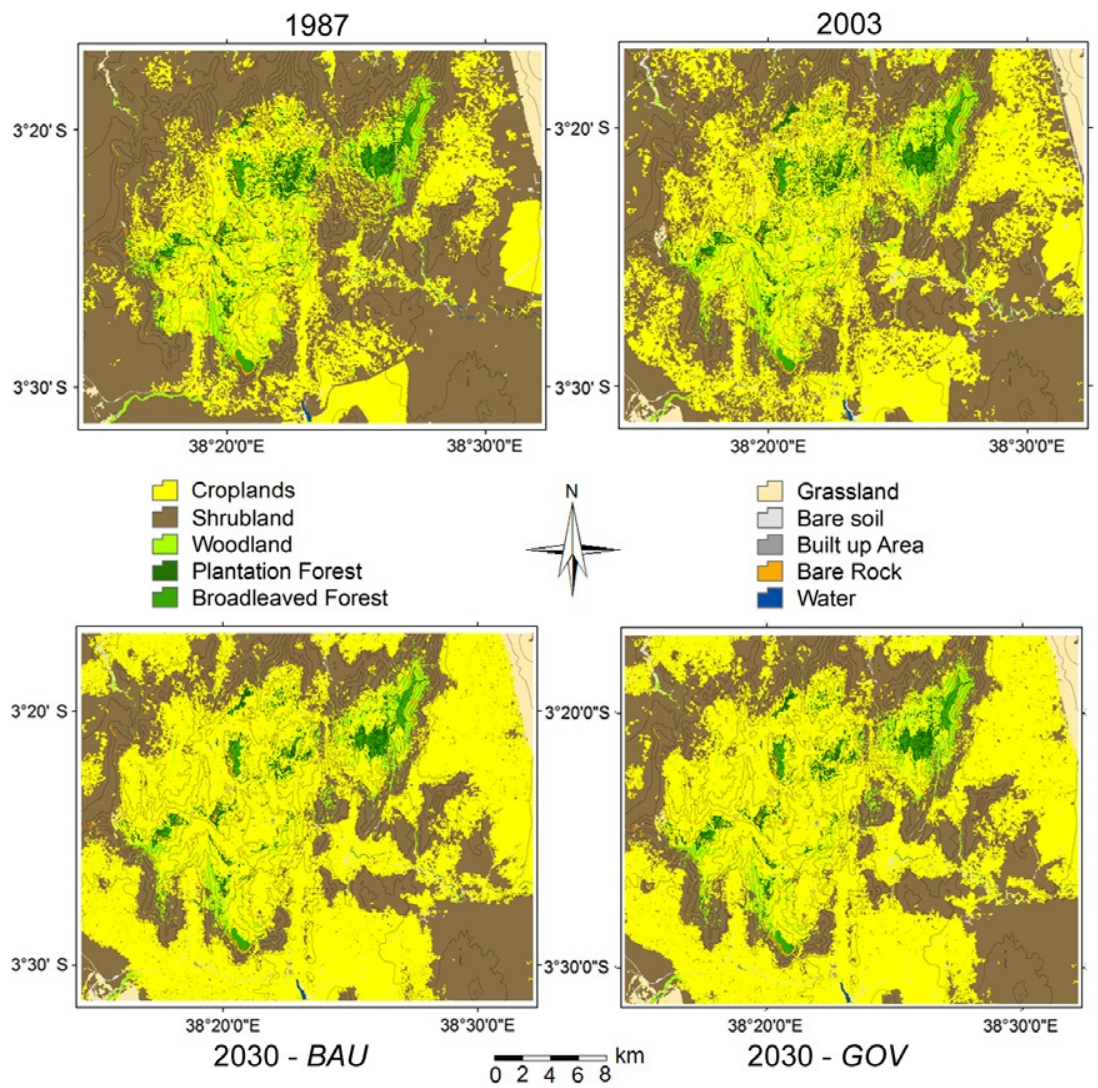

FIGURE 4 Land use maps for 1987 and 2003 (upper left and upper right) and simulated scenarios for 2030 (lower left and lower right). Adapted from Maeda et al. (2010a).

the expansion of croplands is observed in the limits of the protected areas. Hence, although a high environmental pressure is present along the fringes of the conservation areas, such as Tsavo East National Park, the areas inside the park are likely to be preserved.

Between 1987 and 2003, croplands started to be implemented with higher intensity in the lowlands, given that suitable areas for agriculture activities in the highlands were already almost entirely taken. Although each simulated scenario was created independently, using different transition rates, the spatial distribution of new cropland patches followed the same patterns in all simulations. As suitable agricultural areas in the highlands disappeared, the expansion of new patches was distributed in the foothills. Based on the explanatory factors (Maeda et al., 2010a), among the main driving forces of such distribution were the distance to markets (here represented by villages or towns), distance to roads, and distance to rivers. Distance to markets and 
roads played an interesting role in croplands distribution, in the sense that the effects of these two variables in the landscape dynamic were closely related. Towns and villages acted as core points, which are interconnected by roads creating axes in which new cropland patches were settled. Such patterns were observed mainly in the southern and southwestern parts of the study area. It is also important to notice the enhanced importance attributed to rivers in the land use dynamic. Given that in this region, the foothills typically have higher average temperatures and lower precipitation volumes, the proximity to water bodies is essential to the establishment of agricultural activities. The numerical results of the simulations are presented in Figure 5. In the Business As Usual (BAU) scenario, the cropland areas expanded to around $515 \mathrm{~km}^{2}$ in 2030 , corresponding to about $60 \%$ of the study area, representing an increase of $40 \%$ in comparison to the year 2003, when croplands occupied around $365 \mathrm{~km}^{2}$. Although the effects of the governance (GOV) scenario cannot be easily identified in Figure 4, the simulated land use policies resulted in a significant reduction in agricultural expansion. The total area used for agriculture in 2030 for the GOV scenario was approximately $485 \mathrm{~km}^{2}$.

The land-cover changes have direct impact on the cover/management factor $C$ of the USLE model. Previous studies have shown that croplands increase soil exposure to weathering more than original vegetation such as forests or shrublands. For this reason, the $C$ factor of agricultural areas is usually higher, resulting in increased soil erosion rates. The $C$ factor values by Erdogan et al. (2011) indicate that average $C$ increased 10\% from year 1987 to 2003. In the LUCC simulation for the year 2030, $C$ increased by $9 \%$ from 2003. The areas with higher slope values are likely to undergo higher soil erosion rates, and when new fields are located in steep slopes, the soil erosion

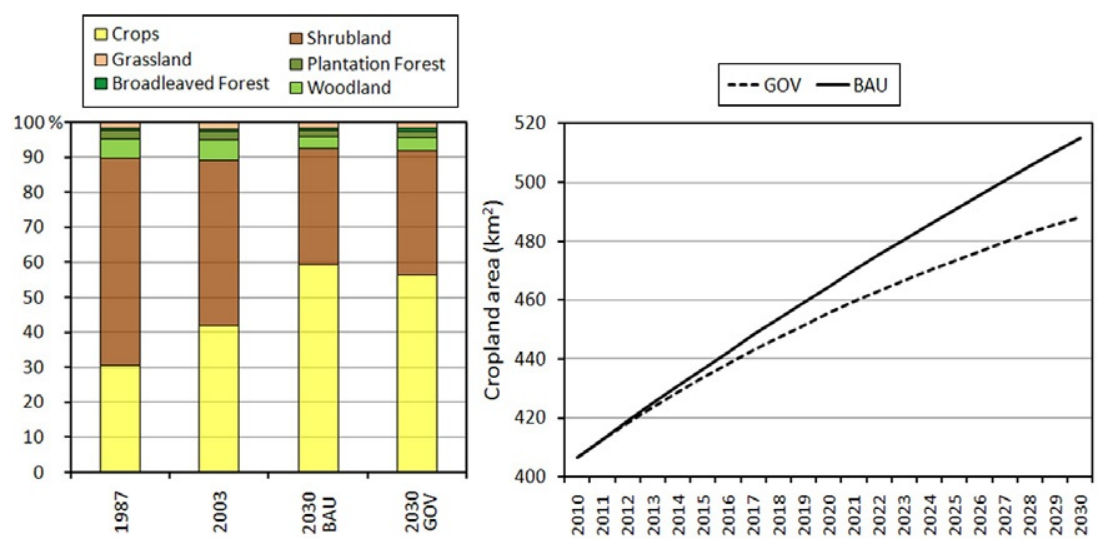

FIGURE 5 (a) Percentage of the main land use/land-cover classes during the years 1987 and 2003 and in both scenarios simulated for 2030 and (b) LUCC simulation results from 2010 to 2030. Adapted from Maeda et al. (2010a). 
potentiality is even greater. Fortunately, this is not the case in the Taita Hills. Agricultural patches established in the last decades were mainly settled in areas with favourable topography. This pattern was reinforced after 1987, when the availability of space in the hills was scarce and the agriculture started expanding to flat areas along the foothills. In the agricultural expansion simulated for 2030, a slight increase in cropland patches has occurred in steeper slopes; however, the most significant increase has occurred again in areas with gentle slopes or even flatlands.

\section{DISCUSSION: ENDANGERED ECOSYSTEM SERVICES}

Land-cover change has numerous ecological, physical and socioeconomic consequences. On the positive side, agricultural expansion may increase food production for a growing population, although it is unsure how productive the last exploited lands will be as they are typically the least favourable. There are numerous negative consequences with both known and unknown links and feedback mechanisms.

Converting the natural vegetation to agricultural land is likely to change the radiation balance of the given unit of area. In principle, the albedo increases as land is without vegetation at least part of the year causing more solar energy to reflect back to the space. Other environmental impacts include the decrease in soil water-holding capacity. As natural vegetation is replaced by agriculture, soil porosity may be reduced by soil compaction, decreasing infiltration capacity and increasing the risks of soil erosion. In mountainous areas, the conversion of the forests to agricultural lands decreases as does the occult precipitation as croplands capture less atmospheric moisture than multilayered indigenous forest or forest of any kind (Holder, 2004). Cloud formation over the land unit also decreases as the evapotranspiration rate is less from fields than from forests causing evidently reduced precipitation.

Further studies project that, by 2030, agricultural land is likely to expand to regions with higher evapotranspiration potential (Figure 6). This expansion will increase by approximately $40 \%$ the annual volume of water necessary for irrigation (Maeda et al., 2011).

As soil water-holding capacity is reduced, the risk of hydrologic droughts during dry seasons is increased, while during the rainy seasons, soils are more susceptible to erosion. These soil loss and sediment-deposition processes may have a significant impact on agriculture, local economies and ecosystems (Alcantara-Ayala et al., 2006). Although increasing evidences indicate that anthropogenic changes in the landscape are likely to lead to regional and global climate change, the levels and scale of this relationship remain largely unknown. However, it is clear that converting forestland to agricultural land causes changes in local climate via the changes in radiation and water balance. Changes in precipitation and temperature patterns will likely have important impacts on the sustainability of agricultural systems. 


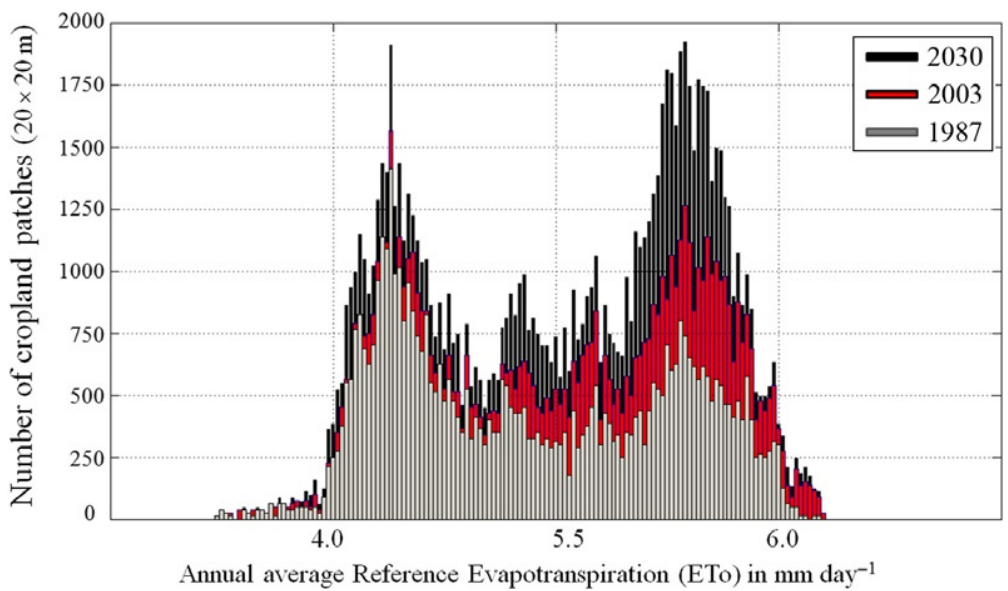

FIGURE 6 Histogram showing the cropland patches distribution during 1987, 2003 and 2030, in relation to the historical average potential evapotranspiration in the Taita Hills. Adapted from Maeda et al. (2011).

The land-cover change taking place in the Taita Hills and its surrounding has been continuing since human settlers arrived in the area and started to convert native vegetation to agricultural land. With ever-growing population and demand for land for cultivation of food crops and other crop types in addition to increase of reserved and protected areas in the study area, land is evidently becoming a valuable natural resource. Land use conflicts have already taken place in the area between farmers, conservationists, settlers and sisal plantation managers (Vanonen, 2008).

Converting natural vegetation, forest or grassland to agricultural areas decreases biodiversity, reduces the capability of vegetation to capture atmospheric moisture and retain water in the vegetation cover, exposes land to be subject to water and wind erosion and changes the radiation balance of the land surface as land is exposed and barren part of the year. These all have still unknown impacts on regional climate.

\section{ACKNOWLEDGEMENTS}

The University of Helsinki is involved in a number of international projects targeting to understand the consequences of the land-cover change in the Taita Hills and in Africa in general. CHIESA project financed by the Ministry of Foreign Affairs of Finland studies the impact of climate and land-cover change to ecosystem services, such as pests and pollinators of avocado, coffee, crucifers and maize, to water resources and to habitats. BIODEV project financed by the Ministry of Foreign Affairs of Finland concentrates to monitor forest and cropland area biomass and aboveground and soil carbon in the Taita Hills and its surroundings and simultaneously develops methods for increasing timber on the farms in order to sequestrate carbon. TAITAWATER project funded by the Academy of Finland 
researches the occult precipitation captured by the forest, water-holding capacity of the forests and human water use in the Taita Hills. For the long-term research programme, the University of Helsinki established Taita Research Station in Wundanyi in 2011 (http://blogs. helsinki.fi/taita-research-station/).

\section{REFERENCES}

Alcantara-Ayala, I., Esteban-Chavez, O., Parrot, J.F., 2006. Landsliding related to land-cover change: a diachronic analysis of hillslope instability distribution in the Sierra Norte, Puebla, Mexico. Catena 65, 152-165.

Baldyga, T.J., Miller, S.N., Driese, K.L., Gichaba, C.N., 2007. Assessing land cover change in Kenya's Mau Forest region using remotely sensed data. Afr. J. Ecol. 46, 46-54.

Beentje, H.J., Ndiang'ui, N., 1988. An ecological and floristical study of the forests of the Taita Hills, Kenya. Utafiti 1 (2), 23-66.

Brink, A.B., Eva, H.D., 2009. Monitoring 25 years of land cover change dynamics in Africa: a sample based remote sensing approach. Appl. Geogr. 29 (4), 501-512.

Bytebier, B., 2001. Taita hills biodiversity project report. National Museums of Kenya, Nairobi, $121 \mathrm{pp}$.

Clark, B.J.F., 2010. Enhanced Processing of SPOT Multispectral Satellite Imagery for Environmental Monitoring and Modelling, Department of Geosciences and Geography A5, University Print, Helsinki. http://urn.fi/URN:ISBN:978-952-10-6306-0.

Clark, B.J.F., Pellikka, P.K.E., 2009. Landscape analysis using multi-scale segmentation and object-oriented classification. In: Röder, A., Hill, J. (Eds.), Recent Advances in Remote Sensing and Geoinformation Processing for Land Degradation Assessment. Taylor \& Francis, Leiden, pp. 323-342.

Di Gregorio, A., 2005. Land Cover Classification System (LCCS), Version 2: classification Concepts and User Manual. In: Food and Agriculture Organization (FAO) Environmental and Natural Resources Series8FAO, Rome.

EAWLS, 2005. East African Wildlife Society: Stakeholders Workshop on the Conservation and Management of Taita Hills Forests-Workshop Summary Report.

Erdogan, E.H., Pellikka, P., Clark, B., 2011. Impact of land cover change on soil loss in the Taita Hills, Kenya between 1987 and 2003. Int. J. Remote Sens. 32 (21), 5919-5945.

Eva, H.D., Brink, A., Simonetti, D., 2006. Monitoring Land Cover Dynamics in Sub-Saharan Africa. A Pilot Study Using Earth Observing Satellite Data from 1975 and 2000. Institute for Environment and Sustainability, Joint Research Centre of the European Commission, $44 \mathrm{pp}$.

Gonsamo Gosa, A., 2009. Remote Sensing of Leaf Area Index: Enhanced Retrieval from CloseRange and Remotely Sensed Optical Observations. In: Helsingin yliopiston maantieteen laitoksen julkaisuja A147Hansaprint, Helsinki. http://urn.fi/URN:ISBN:978-952-10-5873-8.

Hildebrandt, J.M., 1877. Von Mombassa nach Kitui. Zeitsch. Gesellsch. Erdkunde 14, 321-350.

Himberg, N., 2011. Traditionally Protected Forests-Justifications or Hindrances to Ethnodevelopment and Participatory Forestry in Taita Hills, Kenya. Department of Geosciences and Geography, University Print, Helsinki. http://urn.fi/URN:ISBN:978-952-10-7283-3.

Himberg, N., Omoro, L., Pellikka, P., Luukkanen, O., 2009. The benefits and constraints of participation in forest management. The case of Taita Hills, Kenya. Fennia 187 (1), 61-76.

Holder, C.D., 2004. Rainfall interception and fog precipitation in a tropical montane cloud forest of Guatemala. Forest Ecol. Manage. 190, 373-384. 
Imbernon, J., 1999. Pattern and development of land use changes in Kenyan highland since 1950s. Agric. Ecosyst. Environ. 76, 67-73.

Lens, L., Van Dongen, S., Norris, K., Githiru, M., Matthysen, E., 2002. Avian persistence in fragmented rainforest. Science 298, 1236-1238.

Lovett, J.C., Wasser, S.K., 1993. Biogeography and Ecology of the Rainforests of Eastern Africa. Cambridge University Press, Cambridge.

Lung, T., Schaab, G., 2006. Assessing fragmentation and disturbance of west Kenyan rainforests by means of remotely sensed time series data and landscape metrics. Afric. J. Ecol. 44, 491-506.

Maeda, E.E., 2011. Agricultural expansion and climate change in the Taita Hills, Kenya: an assessment of potential environmental impacts. Department of Geosciences and Geography A7, University Print, Helsinki. https://helda.helsinki.fi/handle/10138/24585.

Maeda, E.E., Clark, B.J.F., Pellikka, P.K.E., Siljander, M., 2010a. Modelling agricultural expansion in Kenya's eastern arc mountains biodiversity hotspot. Agric. Syst. 103, 609-620.

Maeda, E.E., Pellikka, P.K.E., Siljander, M., Clark, B.J.F., 2010b. Potential impacts of agricultural expansion and climate change on soil erosion in the Eastern Arc Mountains of Kenya. Geomorphology 123, 279-289.

Maeda, E.E., Pellikka, P.K.E., Clark, B.J.F., Siljander, M., 2011. Prospective changes in irrigation water requirements caused by agricultural expansion and climate changes in the eastern arc mountains of Kenya. J. Environ. Manage. 92, 982-993.

Maro, P.S., 1988. Agricultural land management under population pressure: the Kilimanjaro experience, Tanzania. Mt. Res. Dev. 8, 273-282.

McMichael, C.E., Hope, A.S., 2007. Predicting streamflow response to fire-induced landcover change: implications of parameter uncertainty in the MIKE SHE model. J. Environ. Manage. 84, 245-256.

Muya, E.M. \& Gicheru, P.T. (2005). Assessment of land degradation and its impacts on land use sustainability in Taita Taveta catchment. Miscellaneous Paper No. 63, Kenya Agricultural Research Institute, Kenya Soil Survey, Nairobi.

Omoro, L.M.A., 2012. Impacts of Indigenous and Exotic Tree Species on Ecosystem ServicesCase Study on the Mountain Cloud Forests of Taita Hills, Kenya. In: Tropical Forestry Reports41Viikki Tropical Resources Institute, University of Helsinki. http://urn.fi/URN: ISBN:978-952-10-8449-2.

Omoro, L.M.A., Pellikka, P., Rogers, P., 2010. Tree species diversity, richness, and similarity between exotic and indigenous forests in the cloud forests of Eastern Arc Mountains, Taita Hills, Kenya. J. Forest. Res. 21 (3), 255-264.

Pellikka, P., 1990. Land Use and Its Classification Using a Multispectral SPOT XS Satellite Image in the Taita Hills, SE Kenya. Unpublished M.Sc. Thesis. University of Helsinki, Faculty of Science, Department of Geography, Helsinki 1990.

Pellikka, P., Lötjönen, M., Siljander, M., Lens, L., 2009. Airborne remote sensing of spatiotemporal change (1955-2004) in indigenous and exotic forest cover in the Taita Hills, Kenya. Int. J. Appl. Earth Obs. Geoinf. 11, 221-232.

Rogers, P.C., O'Connell, B., Mwangombe, J., Madoffe, S., Hertel, G., 2008. Forest health monitoring in the Ngangao forest, Taita Hills, Kenya: a five year assessment of change. J. East Afric. Nat. Hist. 97 (1), 3-17.

Siljander, M., 2010. Geospatial environmental data modelling applications using remote sensing, GIS and spatial statistics. Department of Geosciences and Geography A1, Yliopistopaino, Helsinki. http://urn.fi/URN:ISBN:978-952-10-6110-3. 
Soini, E., 2006. Livelihood, land use and environment interactions in the highlands of East Africa. https://helda.helsinki.fi/handle/10138/21188.

Sombroek, W.G., Brown, H.M.N., van der Pouw, B.J.A.,1980. The Exploratory Soil Map and Agro-climatic Zone Map of Kenya. Report No. E1 (Nairobi: Kenya Soil Survey).

Sunderlin, W.D., Ndoye, O., Bikié, H., Laporte, N., Mertens, B., Pokam, J., 2000. Economic crisis, small-scale agriculture, and forest cover change in southern Cameroon. Environ. Conserv. 27, 284-290.

Turner, R.M., Ochung, H.A., Turner, J.B., 1998. Kenya's Changing Landscape. The University of Arizona Press, Tucson, 177 pp.

Vanonen, J., 2008. The conflicts of land in Taita Taveta District, Kenya. Unpublished M.Sc. Thesis. University of Helsinki, Faculty of Science, Department of Geography, Helsinki 1990.

Wischmeier, W.H., Smith, D.D., Uhland, R.E., 1958. Evaluation of factors in the soil loss equation. Agric. Eng. 39, 458-462. 